For further information, contact Dr. J. Hendekovic, Head of EURESCO Unit, European Science Foundation, 1 quai Lezay-Marnésia, 67080 Strasbourg Cedex, France, E-mail: euresco@esf.org; Tel.: +33 3887671 35; Fax: +33 3883669 87; Web site: http:// www.esf.org/euresco.

\section{Workshop on Local and Regional Contribution to Air Pollution and Local Radiative Balance in Asian Developing Countries, 29-31 October 2001, Guangzhou, China}

With rapid urbanization and industrialization, many cities in Asia and in developing countries elsewhere suffer from serious air pollution. The problem is considered basically a local urban air pollution problem, but it is also a regional and global matter. This workshop is designed to bring researchers and policy makers together with invited experts to analyze the problem jointly and to determine the extent and influence of regional air pollution on the local problem. A "lo- cal" pollutant, fine particles, is getting a lot of attention, not only because aerosols have effects on human health but also because they are an important factor in the local radiative balance. At the end of the workshop, a framework of abatement strategy will be drafted and suggested for decision-makers.

Proposed sessions at the workshop will include discussions of photochemical oxidants (formation, field monitoring, and laboratory simulation and modeling); aerosols (fine particle PM2.5, health implications, regional air pollution, and global changes); and policy (optimized framework of abatement strategy for local and regional air pollution). Organizers of the workshop will include IUPAC's Commission on Atmospheric Chemistry (VI..2), Peking University's Center of Environmental Sciences, the Guangzhou Research Institute of Environmental Protection, and the Netherlands Energy Research Foundation (ECN).

For additional information, contact Mr. Yougqiang Cao, Center of Environmental Sciences, Peking University, Beijing 100871, China; E-mail: yhzhang@ ces.pku.edu.cn; Tel.: +8610 62756592; Fax: +8610 62751927.

\title{
Conference Calendar
}

Visit http://www.iupac.org for complete information and further links.

NEW designates a new conference since the last issue.

\section{1}

\section{Macromolecules}

9-11 April 2001

$4^{\text {th }}$ Annual UNESCO School and South African IUPAC Conference on Macromolecules and Materials Science, Johannesburg, South Africa.

Prof. R. D. Sanderson, UNESCO Associated Centre for Macromolecules and Materials, Institute for Polymer Science, University of Stellenbosch, Private Bag X1, Matieland 7602, South Africa Tel.: +27 218083172

Fax: +27218084967

E-mail:rds@maties.sun.ac.za

\section{Chemistry and Chemical} Engineering

16-20 April 2001

IV International Congress on Chemistry and XIII Caribbean Conference on Chemistry and Chemical Engineering, Havana, Cuba.

Prof. Alberto J. Núñez Sellés, Sociedad Cubana de Química, Ave 21\&200, Atabey, Apdo. 16042, CP 11600, Havana, Cuba. Tel.: +537218178

Fax: +537336 471

E-mail: cqf@cqf.co.cu

\section{Free-Radical Polymerization}

3-8 June 2001

$3^{\text {rd }}$ International Symposium on

Free-radical Polymerization:

Kinetics and Mechanism, Lucca, Italy.

Prof. M. Buback, Institute for

Physical Chemistry, University of
Göttingen, Tammannstr. 6, D37077 Göttingen, Germany

Tel: +49551393141

Fax: +49551393144

E-mail: mbuback@gwdg.de

\section{CHEMRAWN XIV}

9-13 June 2001

Chemrawn Conference-Toward Environmentally Benign Processes and Products, Boulder, Colorado, USA. Dr. Dennis L. Hjeresen, Environmental Management Program, Los Alamos National Laboratory - Mail Stop J591, Los Alamos, NM 87545.

Tel.: +15056657251

Fax: + 15056658118

E-mail:dennish@lanl.gov 